\title{
STUDY ON EFFECT OF STOREY HEIGHT ON THE SEISMIC PERFORMANCE OF TALL BRACED BUILDINGS
}

\author{
A.Mallika \\ Professor, Department of Civil Engineering, VNR VJIET, Hyderabad, India.
}

\begin{abstract}
Present trend of high-rise buildings in the urban scenario, there is necessity for finding effective and efficient forms of bracing systems to be used in high rise buildings to resist lateral loads. Various bracing patterns perform differently under different storey heights. The present study aims at finding the effect of storey height on the structural responses of tall braced buildings.Response spectrum analysis is performed to investigate the structural responses like lateral displacements, storey shears, storey drifts and Overturning moments.The bracing patterns studied in the present paper are diagonal, $X, V$ and inverted V-bracings. 10-storeyed building with $3.0 \mathrm{~m}, 3.6 \mathrm{~m}$ and $4.2 \mathrm{~m}$ storeyheights is considered in zone $V$ for the present study. In the present paper, ETABS software is used for investigating the structural responses of Tall Buildings.
\end{abstract}

Keywords: Bracing Patterns, Tall Buildings, Response spectrum analysis, storeyshears, storey drifts and Overturning moment

\section{INTRODUCTION}

Tall buildings must be designed to resist the lateral forces effectively in addition to gravity forces, both permanent and transitory.The function of the lateral load resisting systems is to carry the earthquake loads and transfer the lateral forces on the building safely to the ground.

Braced framesare quite stiff and often used in very tall buildings. Truss action is formed by introducing diagonal members into structural frame of rectangular portions. It helps to increase the lateral stiffness of the frame against lateral forces from earthquakes.The design of braced Framesis done with simple beam-to-column connections where only shear transfer takes place andare combined with moment resisting frames. In the analysis, only the tension brace is considered to be effective.

\section{Bracing Behaviour Under Lateral Loads:}

The most efficient methods of resisting lateral loads is bracing the moment resisting framein either direction. The primary purpose of bracing is to resist horizontal shear induced due to the lateral forces. The horizontal shear resisting mechanism can be understood by following the path of horizontal shear along the frame. By considering different types of bracings the lateral load carrying mechanism can be understood. When diagonal braces are subjected to compressive forces, the horizontal web members will undergo axial tension for equilibrium in lateral direction and vice versa. This will result in shear deformation of bent brace. Forces and deformations in each member of braced bent will be reversed as the frame is subjected to lateral loading in antithesis direction.

\section{LITERATURE REVIEW}

The literature review reported that research on bracing systems is investigated by many authors. Ashik S. Parasiya [1] has done a comparative study of RC brace frame structure with conventional lateral load resisting frame with different type of bracings and concluded that bracing system increases the stiffness and ductility of the structure on the application of the seismic force.MohamedFadil Kholo Mokin [2] has done study on multistory buildings of 10,20 and30 stories in different seismic zones and different soil types. Authors have shown that the displacement values and base shears obtained in bracingstructurural models, does not shows much variations, these values are found to be almost identical, this statement is true in all types of soils, for different heights and for all loading conditions.HomayoonEstekanchi, Ahmad Soltani, AbolhassanVafai [3], have discussed on Seismic behavior of an Off-center Bracing System (OBS). T.Balogh and L. G. Vigh[4] focused to determine the optimal configurations by a numerical method using genetic algorithm approach, developed by the authors. Many other authors [ 5,6] have done studies on effect of structural responses on the differently braced buildings.

However, studies on effect of storey height of differently braced buildings are done by few researchers. The present study aims at finding the structural responses due to different storey heights of braced tall buildings.

\section{PRESENT STUDY}

Numerical study:

\subsection{Geometry:}


In the present study a rectangular buildingof $25 \mathrm{~m} \times 16$ mwith 3 different storeyheights $3.0 \mathrm{~m}, 3.6 \mathrm{~m}, 4.2 \mathrm{~m}$ with 4 different types of bracing patterns namely diagonal, $\mathrm{X}, \mathrm{V}$ and inverted Vare considered. The plan of the rectangular building is as shown in figure 1 .

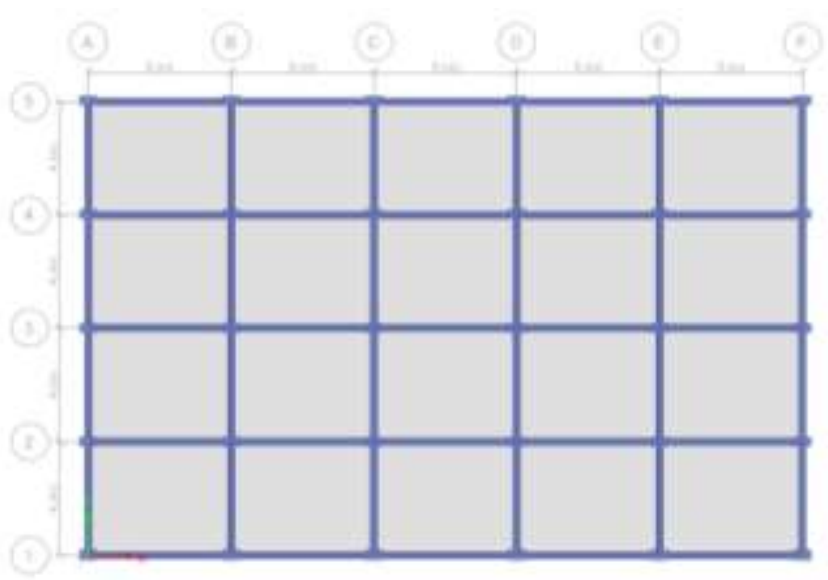

Fig.1 Rectangular plan of $25 \mathrm{~m} \times 16 \mathrm{~m}$
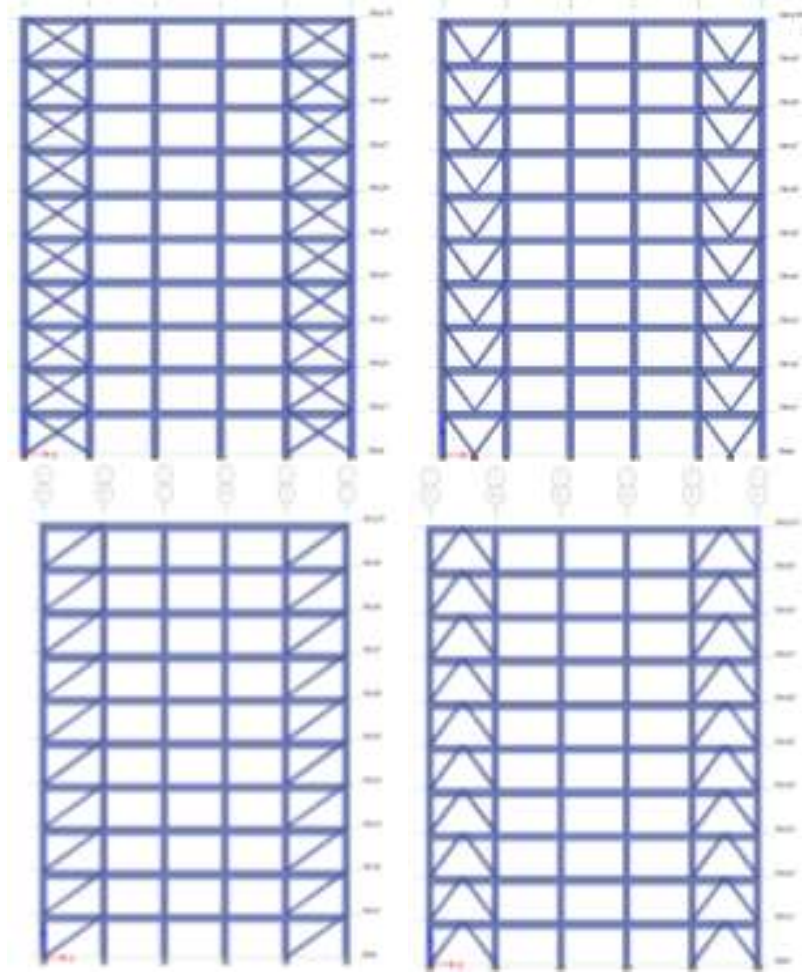

Fig.2 X-bracing, V-bracing, Inverted V-bracing, Diagonal bracings

\subsection{Loads \& Design parameters:}

Loads and load combinations are considered as per the Indian Standards

\section{Gravity loads:}

Floor load and member loads are calculated as per general considerations IS 875-part-1.
Live load for floors is taken as $2 \mathrm{kN} / \mathrm{m}^{2}$ for Residential Buildings and for roofs $1.5 \mathrm{kN} / \mathrm{m}^{2}$ as per IS 875 -part- 2 .

\section{Infill loads:}

Density of brick loading is taken as $20 \mathrm{kN} / \mathrm{m}^{3}$,

External wall thickness $=230 \mathrm{~mm}$, internal wall thickness $=150 \mathrm{~mm}$.

Height of the wall=3 m, $3.6 \mathrm{~m}$ and $4.2 \mathrm{~m}$

\section{Seismic loading:}

Following assumptions are used for the calculation as per IS-1893:2002

Zone factor $=0.36($ zone $\mathrm{V})$

Soil type -2 (medium soil)

Importance factor $=1$

Damping coefficient $=5 \%$

Response reduction factor $=5(\mathrm{SMRF})$

\section{RESULTS AND DISCUSSIONS}

The 3-D models discussed in this section are modeled in ETABs software and are analyzed by Response Spectrum Method. The structural responses like storey displacements, storey shears, storey drifts and over turning moment obtained in $\mathrm{X}$ and $\mathrm{Y}$ directions are compared and presentedfor the braced frames.

\subsection{Base shear:}

Base shear is the expected maximum lateral force at the base of a structure due to groundmotion. The maximum base shear obtained in X,Yplan directions is shown below.

Table 1 - Maximum Base Shear (kN)

\begin{tabular}{|l|c|c|c|c|c|c|}
\hline Direction & \multicolumn{3}{|c|}{ X-Direction } & \multicolumn{3}{c|}{ Y-Direction } \\
\hline $\begin{array}{l}\text { Storey } \\
\text { height }\end{array}$ & $\begin{array}{c}\mathbf{3 . 0} \\
\mathbf{m}\end{array}$ & $\begin{array}{c}\mathbf{3 . 6} \\
\mathbf{m}\end{array}$ & $\begin{array}{c}\mathbf{4 . 2} \\
\mathbf{m}\end{array}$ & $\begin{array}{c}\mathbf{3 . 0} \\
\mathbf{m}\end{array}$ & $\begin{array}{c}\mathbf{3 . 6} \\
\mathbf{m}\end{array}$ & $\begin{array}{c}\mathbf{4 . 2} \\
\mathbf{m}\end{array}$ \\
\hline $\begin{array}{l}\text { Without- } \\
\text { Bracing }\end{array}$ & 4415 & 4026 & 3735 & 3559 & 3231 & 2988 \\
\hline X-Bracing & 4531 & 4109 & 3983 & 3625 & 3322 & 3072 \\
\hline $\begin{array}{l}\text { Diagonal- } \\
\text { bracing }\end{array}$ & 4465 & 4183 & 3786 & 3572 & 3276 & 3030 \\
\hline $\begin{array}{l}\text { V-Bracing } \\
\text { Inverted } \\
\text { V-Bracing }\end{array}$ & 4490 & 4100 & 3815 & 3592 & 3297 & 3052 \\
\hline
\end{tabular}

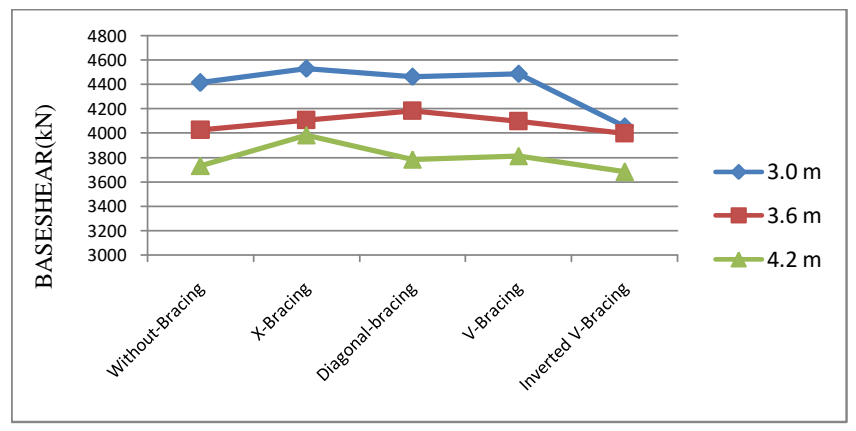

Fig 3: Maximum Base Shear in X-Direction (kN) 
It is observed that the base shears are maximum in the case of building with $\mathrm{X}$ - bracing for a storey height of $3.0 \mathrm{~m}$. The inverted V-braced building depicted low base shear when compared with all buildings for $4.2 \mathrm{~m}$ storey ht. The percentage reduction in base shear for $3.6 \mathrm{~m}$ storey height when compared to $3.0 \mathrm{~m}$ is found to be $1.98 \%$ and $7.92 \%$ in the case of $4.2 \mathrm{~m}$ storey height when compared to $3.6 \mathrm{~m}$.

\subsection{Storey Displacement:}

The maximum displacement obtained for 4 bracing patterns are shown below:

Table 2 - Storey Displacement (mm)

\begin{tabular}{|l|c|c|c|c|c|c|}
\hline Direction & \multicolumn{3}{|c|}{ X-Direction } & \multicolumn{3}{c|}{ Y-Direction } \\
\hline $\begin{array}{l}\text { Storey } \\
\text { height }\end{array}$ & $\begin{array}{c}\mathbf{3 . 0} \\
\mathbf{m}\end{array}$ & $\begin{array}{c}\mathbf{3 . 6} \\
\mathbf{m}\end{array}$ & $\mathbf{4 . 2} \mathbf{~ m}$ & $\begin{array}{c}\mathbf{3 . 0} \\
\mathbf{m}\end{array}$ & $\begin{array}{c}\mathbf{3 . 6} \\
\mathbf{m}\end{array}$ & $\mathbf{4 . 2} \mathbf{~ m}$ \\
\hline $\begin{array}{l}\text { Without- } \\
\text { Bracing }\end{array}$ & 58.6 & 79 & 104.5 & 82.3 & 120 & 166.3 \\
\hline X-Bracing & 32.7 & 43.4 & 54.9 & 39.4 & 53 & 66.7 \\
\hline $\begin{array}{l}\text { Diagonal- } \\
\text { bracing }\end{array}$ & 38.3 & 51 & 64.6 & 45.1 & 60.9 & 77.6 \\
\hline V-Bracing & 35.3 & 48.1 & 62.2 & 43.6 & 60.4 & 78.9 \\
\hline $\begin{array}{l}\text { Inverted } \\
\text { V-Bracing }\end{array}$ & 28.5 & 42.8 & 53.5 & 34.8 & 52.4 & 71.8 \\
\hline
\end{tabular}

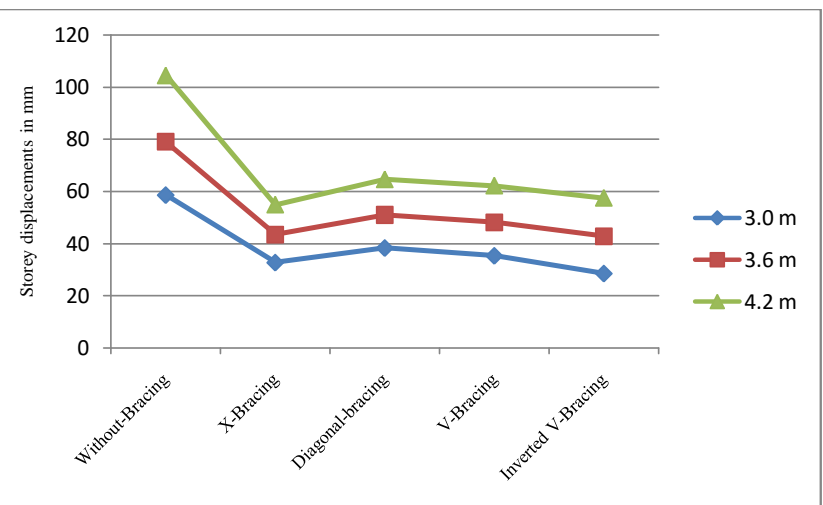

Figure 4 - Maximum Storey displacementsin X-Direction

All the displacements are within permissible limits as per IS:1893and it is obviously observed that less storey height resulted in small storey shears. It is also observed that inverted V-bracings have shown least values compared to other bracing patterns. The increase in the storey displacements in the case of V-bracings for a storey heights of $4.2 \mathrm{~m}$ and $3.6 \mathrm{~m}$ is $87.7 \%$ and $50.17 \%$ respectively when compared to $3.0 \mathrm{~m}$ storey height.

\subsection{Storey Drift:}

Interstory drift is the difference between the displacement of one level relative to other level above or below.As per IS 1893:2002 the storey drift in any storey due to minimum specified desgn lateral force with partial safety factor of 1.0 shall not exceed 0.004 times the storey height.

Table 3 - Storey Drift $\left(10^{-3} \mathrm{~mm}\right)$

\begin{tabular}{|c|c|c|c|c|c|c|c|c|c|c|c|}
\hline \multirow[t]{2}{*}{$\begin{array}{c}\text { Storey } \\
\text { Ht. }\end{array}$} & \multirow[t]{2}{*}{ Storey.No } & \multicolumn{2}{|c|}{ Bare-Frame } & \multicolumn{2}{|c|}{ X-Bracing } & \multicolumn{2}{|c|}{$\begin{array}{c}\text { Diagonal- } \\
\text { Bracing }\end{array}$} & \multicolumn{2}{|c|}{ V-Bracing } & \multicolumn{2}{|c|}{$\begin{array}{c}\text { Inverted V- } \\
\text { Bracing } \\
\end{array}$} \\
\hline & & $X$ & Y & $\mathrm{X}$ & $\mathrm{Y}$ & $\mathrm{X}$ & $\mathrm{Y}$ & $\mathrm{X}$ & $\mathrm{Y}$ & $\mathrm{X}$ & $\mathrm{Y}$ \\
\hline \multirow{10}{*}{$3.0 \mathrm{~m}$} & 1 & 1.86 & 3.52 & 0.72 & 0.79 & 1.06 & 1.24 & 0.87 & 1.15 & 0.61 & 0.73 \\
\hline & 2 & 2.90 & 4.20 & 1.07 & 1.16 & 1.49 & 1.58 & 1.24 & 1.47 & 0.94 & 1.07 \\
\hline & 3 & 2.92 & 3.98 & 1.22 & 1.39 & 1.57 & 1.73 & 1.36 & 1.62 & 1.08 & 1.28 \\
\hline & 4 & 2.75 & 3.71 & 1.30 & 1.52 & 1.59 & 1.80 & 1.41 & 1.70 & 1.16 & 1.39 \\
\hline & 5 & 2.53 & 3.44 & 1.32 & 1.58 & 1.56 & 1.81 & 1.41 & 1.72 & 1.18 & 1.44 \\
\hline & 6 & 2.27 & 3.16 & 1.30 & 1.58 & 1.48 & 1.77 & 1.37 & 1.70 & 1.15 & 1.42 \\
\hline & 7 & 1.96 & 2.83 & 1.23 & 1.53 & 1.36 & 1.67 & 1.29 & 1.62 & 1.08 & 1.36 \\
\hline & 8 & 1.59 & 2.36 & 1.13 & 1.44 & 1.20 & 1.53 & 1.17 & 1.50 & 0.98 & 1.25 \\
\hline & 9 & 1.12 & 1.71 & 1.00 & 1.31 & 1.00 & 1.33 & 1.02 & 1.34 & 0.84 & 1.10 \\
\hline & 10 & 0.61 & 0.87 & 0.82 & 1.15 & 0.76 & 1.08 & 0.83 & 1.14 & 0.66 & 0.90 \\
\hline \multirow{8}{*}{$3.6 \mathrm{~m}$} & 1 & 2.22 & 4.41 & 0.75 & 0.83 & 1.15 & 1.34 & 1.01 & 1.36 & 0.75 & 0.93 \\
\hline & 2 & 3.34 & 5.12 & 1.13 & 1.27 & 1.58 & 1.73 & 1.41 & 1.71 & 1.17 & 1.36 \\
\hline & 3 & 3.30 & 4.85 & 1.32 & 1.54 & 1.69 & 1.92 & 1.54 & 1.88 & 1.35 & 1.61 \\
\hline & 4 & 3.08 & 4.54 & 1.42 & 1.70 & 1.74 & 2.01 & 1.60 & 1.97 & 1.45 & 1.75 \\
\hline & 5 & 2.85 & 4.21 & 1.47 & 1.78 & 1.72 & 2.04 & 1.61 & 2.00 & 1.48 & 1.81 \\
\hline & 6 & 2.60 & 3.85 & 1.45 & 1.80 & 1.67 & 2.02 & 1.57 & 1.98 & 1.46 & 1.82 \\
\hline & 7 & 2.31 & 3.41 & 1.40 & 1.76 & 1.56 & 1.95 & 1.49 & 1.92 & 1.39 & 1.77 \\
\hline & 8 & 1.91 & 2.86 & 1.30 & 1.68 & 1.41 & 1.81 & 1.37 & 1.80 & 1.27 & 1.65 \\
\hline
\end{tabular}




\begin{tabular}{|c|c|c|c|c|c|c|c|c|c|c|c|}
\hline & 9 & 1.35 & 2.09 & 1.17 & 1.55 & 1.20 & 1.61 & 1.20 & 1.62 & 1.10 & 1.46 \\
\hline & 10 & 0.71 & 1.03 & 0.99 & 1.38 & 0.94 & 1.34 & 0.98 & 1.37 & 0.88 & 1.21 \\
\hline \multirow{10}{*}{$4.2 \mathrm{~m}$} & 1 & 2.61 & 5.38 & 0.78 & 0.88 & 1.23 & 1.45 & 1.15 & 1.57 & 0.89 & 1.15 \\
\hline & 2 & 3.82 & 6.08 & 1.20 & 1.37 & 1.68 & 1.88 & 1.58 & 1.95 & 1.35 & 1.64 \\
\hline & 3 & 3.73 & 5.77 & 1.42 & 1.66 & 1.81 & 2.09 & 1.71 & 2.12 & 1.56 & 1.91 \\
\hline & 4 & 3.49 & 5.43 & 1.54 & 1.83 & 1.87 & 2.19 & 1.78 & 2.21 & 1.67 & 2.06 \\
\hline & 5 & 3.24 & 5.05 & 1.59 & 1.92 & 1.87 & 2.24 & 1.79 & 2.25 & 1.72 & 2.14 \\
\hline & 6 & 2.96 & 4.58 & 1.59 & 1.96 & 1.83 & 2.24 & 1.76 & 2.25 & 1.71 & 2.17 \\
\hline & 7 & 2.63 & 4.06 & 1.55 & 1.94 & 1.75 & 2.19 & 1.69 & 2.20 & 1.64 & 2.14 \\
\hline & 8 & 2.19 & 3.44 & 1.46 & 1.88 & 1.60 & 2.07 & 1.56 & 2.09 & 1.52 & 2.03 \\
\hline & 9 & 1.56 & 2.56 & 1.32 & 1.75 & 1.39 & 1.86 & 1.38 & 1.88 & 1.32 & 1.81 \\
\hline & 10 & 0.81 & 1.24 & 1.13 & 1.57 & 1.10 & 1.56 & 1.12 & 1.59 & 1.05 & 1.48 \\
\hline
\end{tabular}

Inter storey drifts are more at third storey in the case of bare frame without bracings at fifth storey in the case of $\mathrm{X}$ bracings, at fourth storey in the case of diagonal bracings, at fifth storey in the case of $\mathrm{V}$ - bracings and inverted $\mathrm{V}$ bracings.

The value increases by $14.38 \%$ for $3.6 \mathrm{~m}$ storey height compared to 3.0 storey height and $14.37 \%$ for $3.6 \mathrm{~m}$ storey height compared to 4.2 storey height in the case of bare rectangular frame, $11.36 \%$ for $3.6 \mathrm{~m}$ storey height compared to 3.0 storey height and $8.16 \%$

for $3.6 \mathrm{~m}$ storey height compared to 4.2 storey height in the case of X-braced frame,

$9.43 \%$ for $3.6 \mathrm{~m}$ storey height compared to 3.0 storey height and $7.47 \%$ for $3.6 \mathrm{~m}$ storey height compared to 4.2 storey height in the case of Diagonal braced frame,
$11.14 \%$ for $3.6 \mathrm{~m}$ storey height compared to 3.0 storey height and $1818 \%$ for $3.6 \mathrm{~m}$ storey height compared to 4.2 storey height in the case of $\mathrm{V}$-braced frame,

$25.42 \%$ for $3.6 \mathrm{~m}$ storey height compared to 3.0 storey height and $1818 \%$ for $3.6 \mathrm{~m}$ storey height $21.13 \%$ compared to 4.2 storey height in the case of inverted Vbraced frame.

\subsection{Overturning Moment:}

Over turning moments obtained from the response spectrum analysis are shown in table 4.

Table 4 - Overturning Moment (kN-m) in X-direction

\begin{tabular}{|l|c|c|c|c|c|c|}
\hline Direction & \multicolumn{3}{|c|}{ X-Direction } & \multicolumn{3}{c|}{ Y-Direction } \\
\hline Storey height & $\mathbf{3 . 0} \mathbf{~ m}$ & $\mathbf{3 . 6} \mathbf{~ m}$ & $\mathbf{4 . 2} \mathbf{~ m}$ & $\mathbf{3 . 0} \mathbf{~ m}$ & $\mathbf{3 . 6} \mathbf{~ m}$ & $\mathbf{4 . 2} \mathbf{~ m}$ \\
\hline Without-Bracing & 64915 & 69539 & 74034 & 83963 & 88006 & 96175 \\
\hline X-Bracing & 67563 & 69328 & 68668 & 87537 & 92075 & 94372 \\
\hline Diagonal-bracing & 66021 & 68081 & 68272 & 85505 & 90339 & 92832 \\
\hline V-Bracing & 66393 & 68469 & 69279 & 86255 & 90906 & 93489 \\
\hline Inverted V-Bracing & 61308 & 68891 & 73189 & 78645 & 91545 & 95051 \\
\hline
\end{tabular}

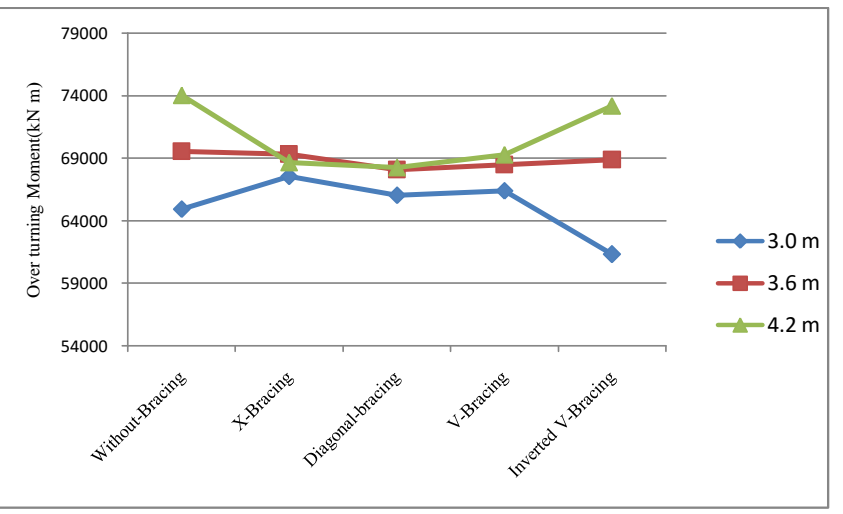

Figure 5 - Maximum Overturning momets Vs type of bracing in X-Direction
It is been observed that overturning moments for storey heights $3.6 \mathrm{~m}$ and $4.2 \mathrm{~m}$ are almost same for diagonal and $\mathrm{X}$ bracing systems.

\section{CONCLUSION}

The structural responsesdue to seismic forces are compared for different storey heights for different bracing patterns as mentioned in section 4 and the conclusions are drawn as below:

- Un-braced and braced rectangular buildingshowed more values of storey displacements, storey drifts revealing that as the storey height increases lateral displacements at each storey as well as maximum lateral displacement increase. 
- Base shears are reduced as the storey height increased. Least values of base shear are observed in the case of inverted V-braced buildings for $4.2 \mathrm{~m}$ storey height when compared against other braced buildings.

- Inter storey drifts are more at third storey in the case of bare frame without bracings at fifth storey in the case of $\mathrm{X}$ - bracings, at fourth storey in the case of diagonal bracings, at fifth storey in the case of $\mathrm{V}$ - bracings and inverted V-bracings for all the storey heights which reveals that distance of point of inflexion from the base i.e fixed end increases as the stiffness of the structure increases.

- Minimum storey drifts are observed in the case of inverted V-braced buildings for all storey heights.

- Maximum value of overturning moments is less in diagonal-bracing.

- Further studies can be done for different soil conditions, different seismic zones and different plan irregularities of the buildings.

\section{REFERENCES}

[1]Ashik S. Parasiya1 Paresh Nimodiya, "Review on Comparative Analysis Of Brace Frame with Conventional Lateral Load Resisting Frame in RC Structure Using Software", International Journal of Advanced Engineering Research and Studies, Oct.-Dec.,2013/88-93, E-ISSN 22498974.

[2]Mohamed Fadil Kholo Mokin" "Performance of Lateral Systems in Tall Buildings for Varying Soil Types", International Journal of Civil Engineering and Technology (IJCIET) Volume 5, Issue 3, March (2014), pp. 15-22.

[3]HomayoonEstekanchi, Ahmad Soltani, AbolhassanVafai, "Seismic Behavior of Steel Frames With Off-Center Bracing System", $13^{\text {th }}$ World Conference on Earthquake EngineeringVancouver, B.C., Canada August 1-6, 2004, Paper No. 1787.

[4] T.Balogh and L.G.Vigh, "Cost Optimization of Concentric Braced Steel Building Structures", World Academy of Science, Engineering and Technology, Vol: 7 2013-06-21, pg: 1016-1025.

[6] IS 1893-2002: "Indian Standard Criteria for Earthquake Resistant Design of Structures" Part-1 General Provisions for Buildings. Bureau of Indian Standards, New Delhi.

[7] IS 456- 2000, "Code of Practice for Plain and Reinforced Concrete” Bureau of Indian Standards, New Delhi 